\title{
INFORMATION TRANSFER TECHNIQUE IN TEACHING WRITING
}

\author{
Ummi Khaerati Syam \& Ismail Sangkala \\ English Education Department, Faculty of Teacher Training and Education \\ Muhammadiyah University of Makassar \\ ummy_talas@yahoo.co.id
}

\begin{abstract}
Writing is one of the language skills that plays important role in human communication. It is used to communicate with other people in society and also to express our opinion in writing form. The teaching of writing requires the students to write accurately. Have a good competence in English does not only mean to be fluent speakers of the language, as many people have in mind but in writing as well; a lot of varieties of occupations requires skilled people in English both in speaking and writing. There are some factors that influence the students' ability to write; they are the vocabulary, the interesting topics given, the interest of students in learning writing such as picture, map, graphic, etc and the time to teach writing in English course or inappropriate technique. Among these factors, technique is an important factor that should be given a special attention because by applying a good technique, the students can improve their ability to organize their ideas into a good writing.

This research is intended to find out the improvement of the students' writing ability by using Information Transfer Technique at first semester students' of Muhammadiyah University of Makassar. The method will use a Pre-Experimental research with the one group pretest and posttest design. The sample is only one class that consisted of 40 students which were selected by using Purposive sampling technique. The data were obtained through writing test.
\end{abstract}

Keyword: Information transfer, writing, teaching, improvement.

According to Palmer (1994:15), Information Transfer is an activity that reproduces either from a full linguistic form into diagrammatic or semi diagrammatic form, or vice versa during the transfer activity, the information remains the same, but the form of information changes for instance, from nonlinguistic form to linguistic form.

For those, we must think the word 'transfer' directly. The word of transfer means change position or made from one position to another. So, information transfer is an activity reproduction from one form into another form. In addition, Short, et al. (1977:144) state that Information Transfer technique is the transformation of instances discourses from one type into another but these instances of discourse can also be derived from a non-verbal mode of communicating." 
It is different from Nation in Husain (1994:15) explains that information transfer as one of the teaching techniques is an excellent strategy for learning and teaching English. A teacher helps the learners develop their language skills. This technique based on the fact that the learner's attention should be entirely on understanding meaning on form oriented procedure in teaching.

a. Why should Information Transfer?

Information transfer activity is the most enjoyable method to organize thought, it is so suitable for teaching and learning English, because the learners can develop their language skill. For example, when the learners are provided with information in the form of table or diagram, they can be motivated or stimulated to organize ideas or thoughts. It can be basic to produce a good writing, because some learners are usually so difficult to find new ideas.

During teaching and learning process of writing, the learners will be provided with series of activity, such as they are asked to look at the table carefully, finding the content of information they get into written form. In transferring the content of information, the learners need to concentrate in arranging and organizing it in order to produce a good writing. Thus, the learning goal can be achieved.

b. The Use of Information Transfer Technique in Writing

Information transfer can be applied in either spoken or written form. In addition both Palmer and Nation in Hussein (1994:17) suggest that information transfer exercises can be used in both skills: receptive and productive. When we are dealing with receptive skill in using information transfer exercises, the learners are given linguistic material. For example, the learners read the information and then they transfer it from what they read into diagram or table. Furthermore, information transfer exercise can also be used productively, that is the learners look at the diagram or table and then they use it as basic of writing.

In this research, the writer will apply productive skill during teaching and learning writing by using information transfer. It requires students to develop ideas or thoughts and it can reinforce their grammatical structure, idiom and 
vocabulary so that the students can improve their ability to organize and formulate ideas into a good writing.

c. The Advantages of Using Information Transfer Technique

Palmer (1991:52) gives some advantages of information transfer technique as follows:

1) It can give variety of teaching technique including four skills: listening, speaking, reading, and writing.

2) It can be used from very wide range of texts.

3) It can be arranged or organize easily that develops learners' ability to organize information.

It is clear that writing by using information transfer technique is more interesting and easier to be taught for students. And it can motivate and stimulate the students in learning English writing.

Writing is one way to recognize our ideas and help us to absorb and process information that can be transferred for the others. Bell and Burnaby in Nadwiah (2002:16), point out that writing is an extremely complex cognitive activity in which the writer is required to demonstrate control of a number of variables simultaneously. At sentence level, these include control of content format, sentence structure, vocabulary, punctuation, spelling letter formation. Beyond the sentence the writer must be able to structure band integrate information into cohesive and coherent paragraphs and texts.

Writing means to produce a message into written language (Pram in Syarman, 2002:25). It involves an activity process to organize and formulate the ideas on the paper. So that reader can catch the writers' message. According to Yarber (1989:2), people can communicate thoughts and feelings to others when they write. It also tells something about themselves. It helps to know who people are, what people believe, and what their purpose are. It is different from Rivers and Temper (1987:20) who state that writing is an exciting, challenging skill that permits students to indulge in fantasy, humor, fiction, or fact in language they 
have chosen to make their own, while drawing on all their inner resources of imagination and self-expression.

From some experts' comments presented above, writing can be defined as a tool of communication to transfer messages or thoughts that are produced in written form in sequence of sentence in a particular order and linked together in certain ways. Through writing, people can connect the various components of the subject matter, their ideas, thoughts, and feelings to each other.

\section{The importance of writing}

Margareta in Hariston (1986:2) states that there are some reasons why writing is important; those reasons are:

a. Writing is a tool for discovery. We stimulate our thought process by the act of writing and into information and image we have in our unconscious mind.

b. Writing generates new ideas by helping to make connection and see the relationship with other aspects.

c. Writing helps us to organize our ideas and clarify concept by writing down ideas into coherent form.

d. Writing helps us to absorb and process information. When we write about the topic, we learn it better.

e. Write on a subject makes us be active learners rather than passive learners of information.

Raimes (1983:3) also states some reasons about the importance of writing. According to him, Writing is used to help the students in learning process. The reasons for that are as follows:

a. Writing reinforces the grammatical structure idiom and vocabulary that have been taught to the students.

b. When students write, they also have a chance to adventure with the language, to go beyond what they have learned to say, to take risks.

c. When the students write, they necessarily become very involved with the new language to express ideas or thinking in paper. 
2. Kinds of writing

According to Dumais (1988:60) there are five kinds of writing; they are:

a. Description

Description is writing to show; it tries to present a picture

b. Narration

Narration is writing to tell story

c. Exposition

Exposition is nonfiction writing. Its basic purpose is to tell about something, to inform or to explain. In the school or in the business world, it is a kind of writing you will do most

d. Argumentation

Argumentation is writing process to convince. It attempts to support, defend or prove a point of view

3. The components of writing

The writing skills are complex and sometimes difficult to teach, requiring mastery not only of grammatical and rhetorical device but also conceptual and judgmental elements. There are five significant components of writing according to Jacob (1981:31); they are content, organization, vocabulary, language use, and mechanics.

a. Content

Treatment of content is the ability to think creatively and develop thoughts, excluding all irrelevant information. The content of writing should be clear to the readers so that the readers understand what the message convey and gain information from it.

b. Organization

Organization (judgment skills) is the ability to write in an appropriate manner for particular purpose with a particular audience in mind together with ability to select, organize and order relevant information. In 
organization, the writing concerns in the ways of writer to arrange and organize the ideas or the messages in the writing.

According to Heaton (1974:138) that judgment skills or organization is the ability of writer to write in an appropriate manner for a particular purpose with a particular audience in mind, also to select, organize and order relevant information. Organization of writing concern with the ways, the writer arranges and organizes the ideas or messages in the writing. It could be chronological order, order of importance, general to particular order, particular to general order.

c. Language use ( Grammar )

Language use is the ability to write correct and appropriate sentences. Grammar plays important roles in the writing. It govern utterances that we produce to be right and orderly. It concerns with tenses, preposition, conjunction, clause (adjective or adverb) and articles.

According to Thomas (2000:21), grammar means the rule which structure our language. In this part also the writer should care about vocabulary.

d. Vocabulary

Vocabulary (stylistic skills) is the ability to manipulate sentences and paragraphs and use language effectively. They should express their ideas in the form of word that is understood by others.

It is clear now that people cannot write and express their idea if they do not have vocabulary. Therefore, they cannot understand the writing passage without having a lot of vocabulary (Mark, 2007:70).

e. Mechanics

Mechanical skills is the ability to use correctly those conventions peculiar to the written language. The use of mechanics is due to capitalization, punctuation and spelling appropriately. This aspect is very important since it leads readers to understand or recognized immediately what the writer means to express definitely. The use of favorable mechanics in 
writing will make reader easy to understand the conveying ideas other message sated in the writing (Thomas, 2000:23).

4. Characteristics of good writing

There are some characteristics of good writing as Adelstein and Pival (1980: XX-XXI) state as follows :

a. Good writing reflects the writer's ability to use appropriate voice. Even though all good writing conveys the sound of someone of talking to someone else, the voice heard through the writing must also suit the purpose and audience of the occasion.

b. Good writing reflects the writer's ability to cruise the first draft and revise it. Revision is the key of effective writing.

c. Good writing reflects the writer's pride in the willingness to spell and punctuate accurately and check word meaning and grammatical relationship within the sentences before submitting the finished product to the audience.

d. Good writing reflects to the writer's ability to organize the material into a coherent whole so that it moves logically from a central, dominant idea to the supporting points and finally to coincident ending conveying to the needs a sense at well thought out plan.

e. Good writing reflects to the writer's ability to write clearly and unambiguously, the sentence structure.

It is different from Neville Grant in Hakim (2005:14) also states the characteristics of good writing exercise namely:

a. Writing exercises should be neither too hard easy. As a rough guide, they should be sufficiently hard to give the students a sense of achievement a sufficient easy for them to be able to make some pride in the result.

b. Writing exercises should not to be long.

c. They should be interesting in their own right. 
It is similar to Nunan (1989:37) points out the successful writing as follow:

a. Mastering the mechanics of writing

b. Mattering and pay attention about spelling and punctuations

c. Organizing content at the level of paragraph and the complete text to reflect the given new information and topic comment structures

d. Publishing and revising one's initial efforts

e. Selecting an appropriate style for one's audience.

5. The purposes of writing

Raimes (1987:36) categories why people need to write into six purposes; they are:

a. Writing for reinforcement

This is for the aim reinforcing students to write in what they have just learnt to understand or say in other to reinforce a grammatical concept that has just been introduced.

b. Writing for training

This is similar to writing to reinforcement, but writing for training rather the purposes of training in initially presents with patterns of linguistics and theoretical that might be new to them and gives them practice in using and manipulating these new patterns.

c. Writing for imitation

The purpose is to make the students familiar with theoretical and second language classrooms use model of content or form as stimulus for writing, their pedagogical purpose differs from that of using writing for reinforcement or for training syntactic form by following carefully chosen models.

d. Writing for communication

The main purpose is to make the students to write in the essential element of writing communication is; of course, there is feedback from the readers. 
e. Writing for fluency

Writing assigned for the purpose of developing fluency than demonstrating accuracy

f. Writing for learning

The purpose is comprehensive enough to include the other purpose in it. When writing for the purpose of learning, it provides the framework for teaching.

\section{BIBLIOGRAPHY}

Adelstein, Michael \& Pival, G. Jean. 1980. The Writing Commitment. New York: Harcourt Brance Jevenovich.

Adil, 2012. Increasing the Students' Writing Ability through Information Transfer at the Second Semester of English Education Department of Tarbiyah and Teaching Science Faculty. Makassar: Thesis of Alauddin State Islamic University.

Aryana, 2007. Using Information Transfer to Develop the Students' Writing Ability. Makassar: States University of Makassar.

Depdikbud, 1985. Petunjuk Pelaksanaan Proses Belajar Mengajar dan Petunjuk Pelaksanaan System Penilaian. Jakarta: Depdikbud.

Dumais, 1988. Writing in English. Jakarta: Depdikbud.

Hairston, Anne Covel, 2002. Teaching English Form, VOL XXIX: 10-11. Hong Kong: City Polytechnic of Hong Kong.

Heaton, J. B, 1974. Writing English Language Test. London: Longman. 1988. English Language Testing. London: Longman.

Husain, Djamiah, 1994. 'Information Transfer' in Jurnal Pendidikan dan Keguruan IKIP, Volume 2 No. 4. Makassar: IKIP Makassar.

Jacob, Holly L, 1981. Testing ESL Composition Profile: A Practical Approach. Rowley Mass: Newbury House Publisher Inc. 
Nunan, David, 1989. Design Task for the Communicative Classroom. New York: Cambridge University Press.

Palmer, D, 1991. Information Transfer for Reading and Listening. China: Thomas Nelson and Son.

Raimes, Ann, 1983. Techniques in Teaching Writing. USA: Oxford University Press.

1987. Why We Need to Write in English Form. USA: Journal Vol. XXV, No. 4.

Rivers, M \& Temper, 1987. A Practical Guide to the Teaching of English as a Second or Foreign Language. New York: Oxford University Press.

Short, M. H., \& Candlin, C. N, 1977. Teaching Study Skills for English Literature. In H.Schiff (Ed). Contemporary Approaches to English Studies. London: Heineman.

Thomas S, Kane, 2000. The Oxford Essential Guide to Write. USA: Oxford University.

Syarman, 2002. The Ability of the Student of SMUN 374 Enrekang to Write Descriptive Composition. Thesis of FBS UNM.

Wahyuni, Sri, 2004. Improving the Ability of the Second Year Students of Madrasah Aliyah Negeri 1 (MAN) Makassar in Writing English Paragraphs Through Description Pictures. Thesis of IAIN Alauddin Makassar.

Yarber, Robert E, 1989. Writing for College. San Diego: Harper Collins Publisher. 